Н. П. Мешко, Д. М. Щитов

Дніпропетровський національний університет імені Олеся Гончара, Украӥна

\title{
ВИСОКОТЕХНОЛОГІЧНІ ПОСЛУГИ ЯК ІННОВАЦІЙНИЙ ФАКТОР РОЗВИТКУ СВІТОВОГО ГОСПОДАРСТВА В УМОВАХ ГЛОБАЛЬНОЇ ЕКОНОМІЧНОЇ ІНТЕГРАЦІЇ
}

\begin{abstract}
Збільшення міжнародної конкуренції на світовому ринку надає актуальності проблемі розвитку високотехнологічного потенціалу країни. Найдинамічнішим сектором світової економіки с високотехнологічні послуги, які належать до найбільш наукомісткого технологічноінтенсивного сектора світового господарства.

Мета написання статті - систематизувати науково-практичні основи дослідження сфери високотехнологічних послуг у контексті глобальної економічної інтеграції. Застосовано загальнонаукові та спеціальні методи досліджень: метод історичного аналізу, метод абстрактнологічного аналізу, теоретичного узагальнення, системний підхід.

У праці високотехнологічні послуги визначено як основний фактор швидкого розвитку національної економіки. Обгрунтовано їх зв'язок зі зростанням значущості знань i перетворенням їх на самостійний фактор виробництва, який безпосередньо впливає на формування національної конкурентоспроможності економік країн та збільшення їх продуктивності.

Зроблено історичний огляд і виявлено, що модель інноваційного розвитку національної економіки трансформувалась у концепцію «знаннсвої економіки», оскільки науковотехнологічна інновація є лише фінальний результат широкого спектра соціально-економічних чинників, багато 3 яких формуються та діють за межами виробництв, де безпосередньо впроваджують інновації. 3'ясовано, що інновації становлять основу розвитку глобальної економіки: компанії сприймають їх як ефективний засіб збільшення прибутків і освоювання нових сегментів ринку, а уряди - як засіб прискорення економічного зростання за допомогою підвищення конкурентоспроможності на глобальних ринках.
\end{abstract}

Наголошено, що високотехнологічні послуги - невід'ємна частина економіки. Вони грунтуються на знаннях і с важливий фактор розвитку світового господарства в умовах глобальної економічної інтеграції. Досліджено основні фактори впливу на ціноутворення високотехнологічних послуг. Обгрунтовано чинники формування ринку високотехнологічних послуг.

Наукова новизна дослідження полягас в систематизації науково-практичної основи розвитку сфери високотехнологічних послуг у контексті глобальної економічної інтеграції.

Практичне значення одержаних результатів - використання вітчизняними вченими матеріалів цісї статті для аналізу ціноутворення й конкурентоспроможності високотехнологічних послуг України на світовому ринку.

Аналіз факторів формування експортного потенціалу високотехнологічних послуг національних економік провідних країн є актуальне наукове завдання для подальшого дослідження.

Ключові слова: високотехнологічні послуги; knowledge-intensive services (KIS); фактори впливу на ціноутворення високотехнологічних послуг.

Н. П. Мешко, Д. М. Щитов

Днепропетровский национальный университет имени Олеся Гончара, Украина

\section{ВЫСОКОТЕХНОЛОГИЧЕСКИЕ УСЛУГИ КАК ИННОВАЦИОННЫЙ ФАКТОР РАЗВИТИЯ МИРОВОГО ХОЗЯЙСТВА В УСЛОВИЯХ ГЛОБАЛЬНОЙ ЭКОНОМИЧЕСКОЙ ИНТЕГРАЦИИ}

Увеличение международной конкуренции на мировом рынке добавляет актуальности проблеме развития высокотехнологического потенциала страны. Динамичным сектором

(C) Мешко Н. П., Щитов Д. М., 2016 
мировой экономики являются высокотехнологические услуги, относящиеся к наиболее наукоемкому технологически интенсивному сектору мирового хозяйства.

Цель написания статьи - систематизировать научно-практические основы исследования сферы высокотехнологических услуг в контексте глобальной экономической интеграции. Применены общенаучные и специальные методы исследований: метод исторического анализа, метод абстрактно-логического анализа, теоретического обобщения, системный подход.

В работе высокотехнологические услуги определены как основной фактор быстрого развития национальной экономики. Обоснована их связь с ростом значимости знаний и превращением их в самостоятельный фактор производства, который непосредственно влияет на формирование национальной конкурентоспособности экономик стран и увеличение их производительности.

Сделано исторический обзор и выявлено, что модель инновационного развития национальной экономики трансформировалась в концепцию « экономики знаний», поскольку научно-технологическая инновация является лишь финальным результатом широкого спектра социально-экономических факторов, многие из которых формируются и действуют за пределами производств, где непосредственно производятся инновации. Выяснено, что инновации составляют основу развития глобальной экономики: компании воспринимают их как эффективное средство увеличения прибыли и освоения новых сегментов рынка, а правительства - как средство ускорения экономического роста посредством повышения конкурентоспособности на глобальных рынках.

Отмечено, что высокотехнологические услуги - неотъемлемая часть экономики. Они основаны на знаниях и являются важным фактором развития мирового хозяйства в условиях глобальной экономической интеграции. Исследованы основные факторы влияния на ценообразование высокотехнологических услуг. Обоснованы факторы формирования рынка высокотехнологических услуг.

Научная новизна исследования заключается в систематизации научно-практической основы развития сферы высокотехнологических услуг в контексте глобальной экономической интеграции.

Практическое значение полученных результатов - использование отечественными учеными материалов статьи для анализа ценообразования и конкурентоспособности высокотехнологических услуг Украины на мировом рынке.

Анализ факторов формирования экспортного потенциала высокотехнологических услуг национальных экономик ведущих стран является актуальной научной задачей для дальнейшего исследования.

Ключевые слова: высокотехнологические услуги; высокие технологии; факторы влияния на ценообразование высокотехнологических услуг.

\author{
N. P. Meshko, D. M. Shitov \\ Oles Honchar Dnipropetrovsk National University, Ukraine
}

\title{
KNOWLEDGE INTENSIVE SERVICES AS INNOVATION DRIVER OF THE WORLD ECONOMY UNDER CONDITIONS OF GLOBAL ECONOMIC INTEGRATION
}

Growing international competition on the world market increases relevance of the problem of development of high technological potential of the country. The most dynamic sector of the world economy is knowledge-intensive services that belong to the most science-intensive and technologyintensive sector of the world economy.

The purpose of writing this article is to systemize scientific and practical bases of research into the area of knowledge-intensive services in the context of global economic integration. General scientific and special research methods were applied: the method of historical analysis, method of abstract-logical analysis, theoretical generalization, systematic approach.

The paper defines knowledge-intensive services as the main factor in the rapid development of the national economy. Their connection to the increasing importance of knowledge and to their converting into a separate factor of production was substantiated, which directly affects the formation of the national competitiveness of the economies of countries and increase in their productivity. 
A historical review was performed and it was discovered that the model of innovative development of national economy transformed into the concept of the "knowledge economy", because scientific and technological innovation is just the final result of a wide range of socio-economic factors, many of which form and operate outside the productions facilities, where innovations are directly implemented. It is shown that innovations form the basis of the development of the global economy: companies perceive them as an efficient means of increasing profits and entering new market segments, while the governments - as a means of accelerating economic growth through competitiveness in global markets.

It is stressed that the knowledge-intensive services are an integral part of the economy. They are based on knowledge and are an important driver in the development of the world economy under conditions of global economic integration. The main factors were investigated that influence the pricing of knowledge-intensive services. The factors of the formation of the market for knowledge-intensive services were substantiated.

The scientific novelty of the research lies in the systematization of scientific and practical bases of the development of knowledge-intensive services in the context of global economic integration.

The practical significance of obtained results is the application of materials of this article by domestic scientists to analyze the pricing and competitiveness of knowledge-intensive services of Ukraine in the world market.

Analysis of the drivers of creation of the export potential of the knowledge-intensive services of national economies of leading countries is a relevant scientific task for further studies.

Keywords: high-tech services, knowledge-intensive services (KIS), drivers of influence on the pricing of high technological services

Вступ. Збільшення міжнародної конкуренції на світовому ринку надає актуальності проблемі розвитку високотехнологічного потенціалу країни. Найдинамічнішим сектором світової економіки $є$ високотехнологічні послуги. У наукових джерелах досліджено розвиток окремих сегментів ринку високотехнологічних послуг, але не розглянуто фактори впливу на ціноутворення високотехнологічних послуг та чинники формування ринку високотехнологічних послуг.

Досліджували тенденції розвитку ринку високотехнологічних послуг українські та російські вчені, а саме: В. В. Смаль, М. Є. Дорошенко, О. Б. Саліхова, Л. І. Федулова, І. В. Туманян, Н. І. Іванова. Серед зарубіжних учених внесок у дослідження цього питання зробили М. Каутонен, Дж. Робертс, Р. Вернер, Е. Мюллер, А. Зенкер, Б. Хермелін, Б. Ловендахл, П. Хертог, С. Скоглі, Т. Мері, М. Родрігес, Дж. Камачо та інші науковці. 3 урахуванням отриманих результатів не дослідженими залишилися фактори формування експортного потенціалу високотехнологічних послуг, що й обумовлює актуальність цієї праці.

Постановка завдання. Мета написання статті - розглянути науковопрактичні основи дослідження сфери високотехнологічних послуг у контексті глобальної економічної інтеграції, дослідити основні фактори впливу на ціноутворення високотехнологічних послуг та обгрунтувати чинники формування ринку високотехнологічних послуг.

Результати. Протягом XVIII-XIX ст. економісти та практики дискутували про природу i роль послуг i виділяли сектор послуг тільки за залишковим принципом: до нього зараховували ті види діяльності, які прямо не належали ні до видобувних, ні до обробних галузей економіки [1].

У XX ст. сектор послуг посів повноцінне місце в економічній моделі світу. У 1935 р. Алан Фішер запропонував увважати сферу послуг третинним сектором економіки. А Колін Кларк ще в першій половині XX ст. передбачив майбутню роль третинного сектора як локомотива економічного зростання. Він також зазначив, що випереджальний темп зростання продуктивності праці гнучкіший порівняно 3 
товарами, попит на послуги мають дати стрімкий розвиток сектора послуг, який приведе до його домінування над іншими секторами [2, с. 35].

У наш час провідну роль у швидкому розвитку світового ринку послуг відіграють саме високотехнологічні послуги, які належать до найбільш наукомісткого технологічноінтенсивного сектора світового господарства. Це пояснюється зростанням значущості знань та перетворенням їх на самостійний фактор виробництва, який безпосередньо впливає на формування національної конкурентоспроможності економік країн та збільшення їх продуктивності.

Значущість цього сектора обумовлюється якісними зрушеннями, які він привносить у традиційні сектори економіки. За допомогою інформаційнокомунікаційних технологій (ІКТ) інтелектуальні послуги запроваджують у традиційних виробництвах, чим різко підвищують їх ефективність і перетворюють їх на елементи нової економіки. Основну роль у сучасній економічній системі відведено компаніям четвертинного сектора, які сприяють поширенню та адаптації нових знань і технологій та самі стають джерелами (виробниками) нових знань.

Економіка знань створює, поширює та використовує знання для забезпечення свого зростання й конкурентоспроможності. Знання впливають на розвиток усіх галузей та секторів національної економіки. Економіка знань не тільки застосовує знання, а й створює їх у вигляді наукової та високотехнологічної продукції, висококваліфікованих послуг, освіти. Тобто можна стверджувати про зростання впливу експортного потенціалу у сфері високих технологій на формування конкурентних переваг у глобальному інноваційному середовищі.

Поширення знань - це головний механізм реалізації економічних вигід від інвестицій у науково-дослідні та дослідно-конструкторські роботи (НДДКР). Попит на НДДКР та інновації - ключовий економічний механізм, що генерує багатства як результат НДДКР, а також діяльність з освоєння і поширення знань.

Концепція економіки знань стала сьогодні основним теоретичним підгрунтям політики економічного зростання національної економіки. Вона розкриває нову роль і місце інтелекту людини в суспільстві.

3 прискоренням розвитку нових технологій доступність знань стає найважливішою умовою для участі країни у глобальній конкуренції. Проаналізувавши відповідні дані дослідження, можна припустити, що існує зворотний зв'язок між рівнем інноваційного розвитку національної економіки і ступенем ефективності експортного потенціалу країни у сфері високотехнологічних товарів та послуг.

На думку науковців, нові технології можуть досить позитивно впливати на економіку країн, незалежно від рівня їх розвитку, що й доводить досвід Китаю, Бразилії, Ірландії, Індії, які за допомогою ефективних систем освіти успішно зайняли сегменти інформаційних технологій і стали конкурентоспроможними на міжнародному ринку в умовах глобальної економічної інтеграції [3, с. 98].

Динаміка розвитку сфери послуг характеризується значними галузевими відмінностями. На думку фахівців, за темпами зростання в усіх країнах лідирує комплекс ділових і професійних послуг. Це служби маркетингу, реклами, менеджменту, лізингу, наукових досліджень, інформаційно-комп'ютерні, консультаційні, аудиторсько-бухгалтерські послуги.

Модель інноваційного розвитку національної економіки трансформувалась у концепцію «знаннєвої економіки», оскільки науково-технологічна інновація є лише результат широкого спектра соціально-економічних чинників, більшість 3 яких формуються та діють за межами виробництв, де безпосередньо впроваджуються 
інновації. Зі значним ускладненням соціальної поведінки суб’ єктів господарювання у зв'язку 3 перетворенням інформації та знань на найбільш інноваційний та прибутковий капітал, зростає невизначеність. Поширення інформаційних технологій оброблення свідомості стає могутнім каталізатором невизначеності сьогодні і в майбутньому.

Згідно 3 теоретичними дослідженнями перехід від індустріального до постіндустріального суспільства відбувається з усебічним розвитком матеріального виробництва, його технічним переозброєнням, зростанням загального й культурного рівня, удосконаленням організації праці та керування. Задоволення потреб споживачів у нематеріальній сфері найчастіше збільшує обсяги матеріальних потреб суспільства (крім продуктів низького рівня переробки, попит на який зменшується у зв'язку 3 упровадженням ресурсо- та енергоощадних технологій) [4, с. 239]. Постіндустріальний етап розвитку економіки характеризується стрімким зростанням масштабів і ступеня впливу знань як ключового фактора.

Володіння різними інноваціями, що виникають у ході використання високотехнологічного ресурсу, і можливість їх застосування обумовлюють рівень технологічності як самого виробництва, так і обслуговуючих його сервісів. Інновації стають основою розвитку глобальної економіки: компанії сприймають інновації як ефективний засіб збільшення прибутків і завоювання нових сегментів ринку, а уряди - як засіб прискорення економічного зростання за допомогою підвищення конкурентоспроможності на глобальних ринках. Отже, на сьогодні високотехнологічні послуги - це невід'ємна частина економіки, що грунтується на знаннях і є важливий фактор розвитку світового господарства в умовах глобальної економічної інтеграції.

Більшість компаній у секторі високотехнологічних послуг зосереджують увагу на якості і ступені задоволеності замовників, цінових характеристиках наданих послуг, довірі та особистісних контактів. А. Кох і Х. Стротманн [5, с. 620] довели, що успіх новоствореної компанії безпосередньо залежить від двох факторів: ступеня функціональної інтеграції 3 основними замовниками та територіальної близькості до них. Найбільша кількість нових компаній, що працюють у секторі високотехнологічних послуг, створюється в безпосередній близькості до великих міських агломерацій 3 найбільш значущими клієнтами [6, с. 230]. Слід зазначити, що в більшості випадків компанії групуються переважно навколо нових послуг, а не за секторальною ознакою.

Іншим фактором, що безпосередньо впливає на розвиток сектора високотехнологічних послуг, $є$ спеціалізація економічного району, в якому розташовано високотехнологічне підприємство. Існує певна специфіка в утворенні структури і величини доданої вартості високотехнологічних послуг (наукоємні послуги - KIS). Так, витрати на сировину і матеріали на KIS-послуги зводяться до мінімуму, а основні витрати йдуть на людський ресурс, оскільки він являє собою дорогу висококваліфіковану працю. Формує додану вартість не тільки наймана праця, а й так звана підприємницька праця, що особливо властиво малим і середнім підприємствам (МСП) високотехнологічної сфери.

Слід зазначити, що KIS-послуги, як правило, мають індивідуальний характер і створюються для конкретного замовника, який виступає в ролі співвиробника послуги. KIS-послуги мають так звану ринкову актуальність (market edge). Споживання інтелектуальних послуг невіддільне від їх виробництва, оскільки сама природа послуг потребує доброго знання не абстрактного споживача, а 
конкретного. Відбувається настільки суттєва інтеграція зовнішнього ресурсу, що деякі вчені пропонують розглядати спільне виробництво послуги [7; 8, с. 359].

Таким чином, участь у співвиробництві високотехнологічної послуги може підвищувати кваліфікацію самого замовника. Тому в науковій літературі часто згадується потужний взаємний вплив сектора високотехнологічних послуг на інноваційність інших секторів [9, с. 129; 10, с. 197].

Оскільки в процесі співвиробництва високотехнологічної послуги обсяг знань замовників збільшується, то, відповідно, може змінитися їх інформованість щодо доступних можливостей даних послуг. Це феномен «переваги гнучкості». Коли економічний суб'єкт стикається 3 невизначеністю стосовно доступних йому сьогодні багатьох альтернатив, він прагне уточнити і змінити зроблене раніше замовлення. Участь споживача у співвиробництві високотехнологічної послуги підвищує його кваліфікацію, але не гарантує перетворення його на інноваційний суб'єкт і можливість сприйняття даної послуги [11].

Для мотивації замовлення і сприйняття KIS-послуги замовник повинен мати необхідність і можливість застосувати високотехнологічну послугу. Тому він має відрізнятися інноваційністю та достатнім рівнем інтелектуального розвитку трудового ресурсу. На формування попиту на ринку високотехнологічних послуг значно впливає рівень цивілізаційного розвитку суспільства, потреба в нових інноваційних послугах суб'єктів ринку і здатність до сприйняття високотехнологічних послуг населенням (рис. 1).

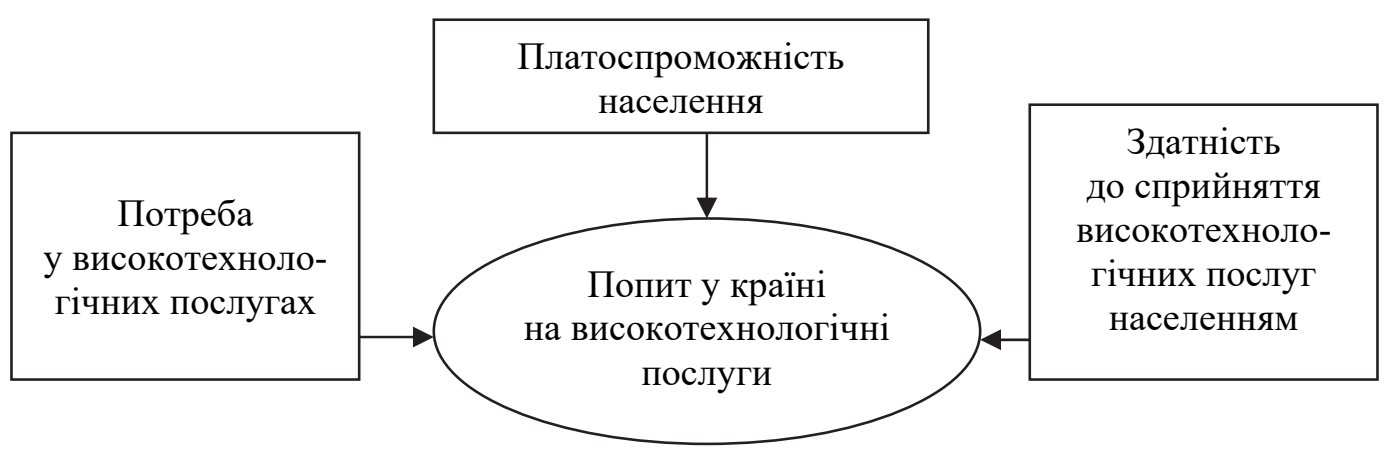

Рис. 1. Чинники формування ринку високотехнологічних послуг

Специфіка надання високотехнологічних послуг полягає, зокрема, у тому, що додана вартість на послуги формується здебільшого в процесі переговорів із замовником, причому останній може суттєво впливати на сукупність компонентів самої послуги. У зв'язку із цим система ціноутворення на високотехнологічні послуги має залежати як від загально-ринкових факторів, так і від індивідуального замовника, а орієнтовна ціна повинна мати тільки нижню межу, що визначатиметься собівартістю виконання цієї KIS-послуги (рис. 2).

За оцінками фахівців, міжнародні компанії постійно працюють над пошуком кращого конкурентоспроможного сервісу, незалежно від їхньої зайнятості у сфері послуг чи у виробничому секторі [12]. Однак більшість заходів, спрямованих на поліпшення діючих послуг, як правило, обмежується потенціальним обсягом додаткових доходів, які вони здатні надати. Тому дуже рідко компанії знаходять високотехнологічні послуги, які здатні або сформувати абсолютно новий ринок, або удосконалити наявні послуги, результатом яких $є$ отримання непередбаченого прибутку протягом певного періоду часу. 


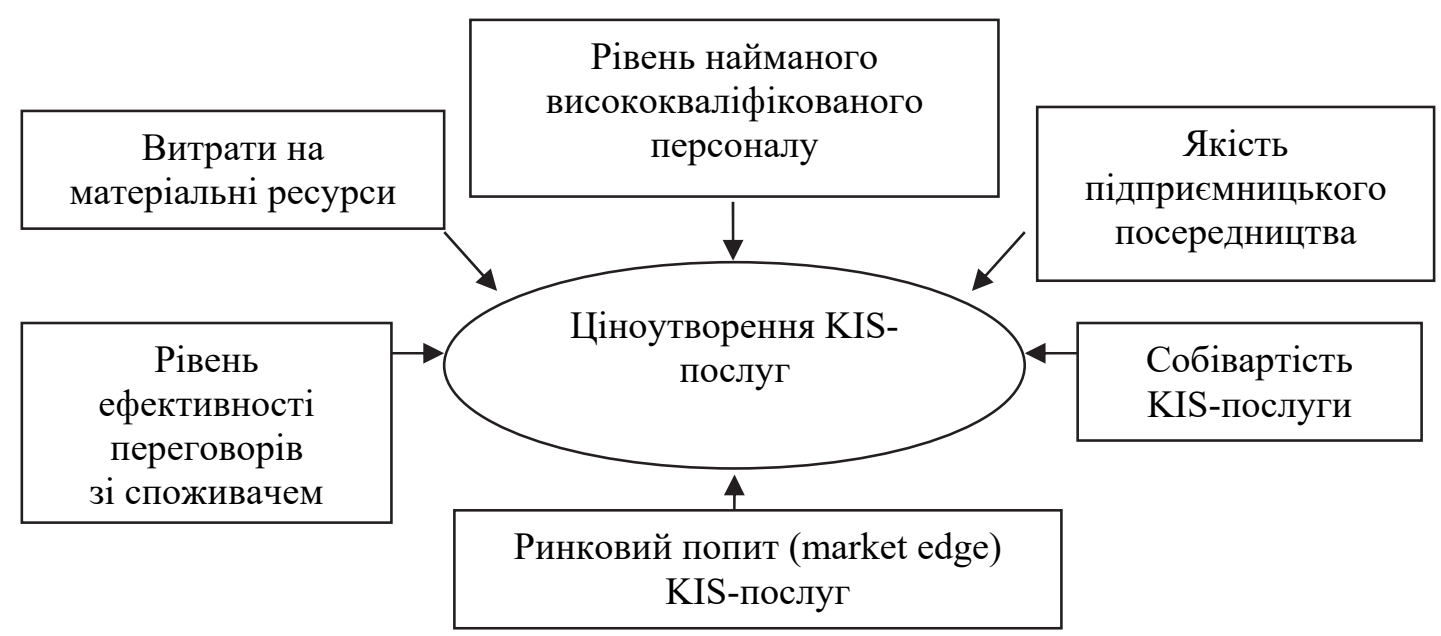

Рис. 2. Фактори впливу на ціноутворення високотехнологічних послуг

Висновки. Високотехнологічні послуги - невід'ємна частина економіки. Вони грунтуються на знаннях і $є$ важливий фактор розвитку світового господарства в умовах глобальної економічної інтеграції. Сучасна інноваційна економіка перетворюється на систему, що функціонує на основі обміну знаннями.

Наукова новизна дослідження полягає в систематизації науково-практичних основ розвідки сфери високотехнологічних послуг у контексті глобальної економічної інтеграції. Досліджено основні фактори впливу на ціноутворення високотехнологічних послуг. Обгрунтовано чинники формування ринку високотехнологічних послуг.

Практичне значення одержаних результатів - використання вітчизняними вченими матеріалів цієї статті для аналізу ціноутворення й конкурентоспроможності високотехнологічних послуг України на світовому ринку.

Аналіз факторів формування експортного потенціалу високотехнологічних послуг національних економік провідних країн $є$ актуальне наукове завдання для подальшого дослідження.

\section{Бібліографічні посилання}

1. Office of science and technology Policy [Electronic resource]. - Access mode: www.ostp.gov/cs/about_ostp. - Title from the screen.

2. Clark, C. Conditions of Economic Progress [Text] / C. Clark. - Macmillan, 1940. -504 p.

3. Шульга, Ж. О. Особливості економіки знань на сучасному етапі розвитку суспільства [Електронний ресурс] / Ж. О. Шульга. - Режим доступу : http://bumib.edu.ua/sites/default/files/visnyk/16-1-17-2012.pdf. - Заголовок з екрана.

4. Мешко, Н. П. Управління інноваційно-інвестиційним потенціалом мезорівня в умовах міжнародної інтеграції [Текст]: монографія / Н. П. Мешко. - Д.: Вид-во ДНУ, 2008. - 428 с.

5. Koch, A. Impact of Functional Integration and Spatial Proximity on the PostEntry Performance of Knowledge Intensive Business Service Firms [Text] / A. Koch, H. Strotmann // International Small Business. - 2006. - Vol. 24, № 6. - P. 610-634.

6. Wagner J. Start-up Activities, Individual Characteristics, and the Regional Milieu : Lessons for Entrepreneurship Support Policies from German Micro Data [Text] / J. 
Wagner, R. Sternberg // The Annals of Regional Science. - 2004. - Vol. 38. - P. 219-240.

7. Gassmann O. Customer Integration in the Early Phase of the Innovation Process [Electronic resource] / O. Gassmann, C. Kausch, E. Enkel. - Access mode: www.alexandria.unisg.ch/publications/17080. - Title from the screen.

8. Strambach, S. Knowledge-Intensive Business Services in the Rhine-Neckar Area [Text] / S. Strambach // Tijdschrift voor Economische en Sociale Geografie. 1994. - Vol. 85, № 4. - P. 354-365.

9. Bilderbeek, R. Technology-based Knowledge-intensive Business Services in the Netherlands : Their Significance as a Driving Force Behind Knowledge-driven Innovation [Text] / R. Bilderbeek, den. P. Hertog // Vierteljahrshefte zur Wirtschaftsforschung. - 1998. - Vol. 67, № 2. - P. 126-138.

10. Katsoulacos, Y. Knowledge-Intensive Business Services and Productivity Growth : The Greek Evidence [Text] / Y. Katsoulacos, N. Tsounis // M. Boden and I. Miles (eds.). Services and Knowledge-Based Economy. - L., 2000. - P. 192-208.

11. Mormul', N. The development of Ukraine's export potential of sphere of knowledge-intensive services in the context of global economic integration [Text] / N. Mormul', D. Shitov, O. Shitov // News of Science and Education. - 2015. № 8 (32).- P. 30-35.

12. Закомурная, К. Як інноваційні послуги створюють нові ринки [Електронний ресурс] / К. Закомурная. - Режим доступу: www.innovations.com.ua/ua/articles/13290/temp. - Заголовок з екрана.

\section{Bibliographic references}

1. Office of science and technology Policy [Electronic resource]. - Access mode: www.ostp.gov/cs/about_ostp.

2. Clark, C. Conditions of Economic Progress [Text] / C. Clark. - Macmillan, 1940. - 504 p.

3. Shulha, Zh. O. Osoblyvosti ekonomiky znan na suchasnomu etapi rozvytku suspilstva [Electronic resource] / Zh. O. Shulha. - Access mode : http://bumib.edu.ua/sites/default/files/visnyk/16-1-172012.pdf.

4. Meshko, N. P. Upravlinnia innovatsiino-investytsiinym potentsialom mezorivnia v umovakh mizhnarodnoi intehratsii : monohrafiia / N. P. Meshko. - D.: Vyd-vo DNU, 2008. - 428 s.Koch A. Impact of Functional Integration and Spatial Proximity on the Post-Entry Performance of Knowledge Intensive Business Service Firms / A. Koch, H. Strotmann // International Small Business. - 2006. - Vol. 24, № 6. - P. $610-634$.

5. Koch, A. Impact of Functional Integration and Spatial Proximity on the Post-Entry Performance of Knowledge Intensive Business Service Firms [Text] / A. Koch, H. Strotmann // International Small Business. - 2006. - Vol. 24, № 6. - P. 610-634.

6. Wagner J. Start-up Activities, Individual Characteristics, and the Regional Milieu : Lessons for Entrepreneurship Support Policies from German Micro Data [Text] / J. Wagner, R. Sternberg // The Annals of Regional Science. - 2004. - Vol. 38. - P. 219-240.

7. Gassmann O. Customer Integration in the Early Phase of the Innovation Process [Electronic resource] / O. Gassmann, C. Kausch, E. Enkel. - Access mode: www.alexandria.unisg.ch/publications/17080.

8. Strambach, S. Knowledge-Intensive Business Services in the Rhine-Neckar Area [Text] / S. Strambach // Tijdschrift voor Economische en Sociale Geografie. - 1994. - Vol. 85, № 4. - P. 354-365.

9. Bilderbeek, R. Technology-based Knowledge-intensive Business Services in the Netherlands : Their Significance as a Driving Force Behind Knowledge-driven Innovation [Text] / R. Bilderbeek, den. P. Hertog // Vierteljahrshefte zur Wirtschaftsforschung. - 1998. - Vol. 67, № 2. - P. 126-138.

10. Katsoulacos, Y. Knowledge-Intensive Business Services and Productivity Growth : The Greek Evidence $[$ Text] / Y. Katsoulacos, N. Tsounis // M. Boden and I. Miles (eds.). Services and Knowledge-Based Economy. - L., 2000. - P. 192-208.

11. Mormul', N. The development of Ukraine's export potential of sphere of knowledge-intensive services in the context of global economic integration [Text] / N. Mormul', D. Shitov, O. Shitov // News of Science and Education. - 2015. - № 8 (32).- P. 30-35.

12. Zakomurnaia, K. Yak innovatsiini posluhy stvoriuiut novi rynky [Electronic resource] / K. Zakomurnaia. - Access mode: www.innovations.com.ua/ua/articles/13290/temp.

Надійшла до редколегії 01.03.2016 